\title{
Response
}

\section{Facing the backlash: sketching the basic humane norms of families' laws}

\author{
Daphna Hacker \\ Buchmann Faculty of Law and NCJW Women and Gender Studies Program, Tel Aviv University \\ ${ }^{*}$ Corresponding author. E-mail: dafna@tauex.tau.ac.il
}

It is a great honour and pleasure to take part in this book symposium. I am deeply grateful to David Nelken for the introduction to this symposium ${ }^{1}$ and to all six commentators for their excellent summaries of the various chapters of my book and for their insightful comments. I am particularly grateful to Susan Boyd for initiating and organising this symposium. As many other instances demonstrate, Boyd is a role model of feminist academia in practice as well as in substance. I appreciate the rare attention my book has received, including as co-winner of the 2018 Law \& Society Association Herbert Jacob Prize for Best Book in Law and Society, and perceive it as an encouraging sign of a growing recognition of the importance of families in legal, sociological and socio-legal scholarship (see also Hacker (2019)).

As Shahar Lifshitz (2019) and Arianne Renan Barzilay (2019) argue in their commentaries, and as I myself have admitted (Hacker, 2017; 2019), the book is hesitant in offering concrete and detailed legal reforms. Likewise, as Nina Kohn (2019) notes, much of the book is an invitation to further study, which is so urgently needed for informed and contextualised regulation of families in the era of bordered globalisation. Notwithstanding, several developments that have occurred since its publication, including the election of nationalist and misogynist leaders in several countries ${ }^{2}$ and unprecedented cruelty towards families of people who attempt to cross national borders ${ }^{3}$ (see also Boyd (2019)), highlight the normative significance of the book and the importance of the knowledge already acquired on families in our time. Indeed, we live in an era in which the basic building blocks of democracy, as well as the many achievements of the feminist struggle, are under attack - including by fake news and hijacking of the human rights discourse by racist and misogynist voices. Hence, while I would like to think my commitment in the book to a humane society, to gender equality and to the right of all people to family life is a basic given that is universally shared, sadly the prominence of such voices shows otherwise.

I would like to devote this response to one development in particular: a recent court decision of the Israeli Supreme Court. This controversial decision not only has a globordered legal angle that was not explored in the book, but also provides an example of the recent dangerous anti-feminist backlash. Further, it is connected to several observations made by my colleagues in their commentaries in this symposium, highlighting the relevance of the book to all families - both the globordered and those who stay within national and cultural boundaries. Finally, it might illuminate Boyd's experience and explain why it was an Israeli - rather than a Canadian - professor who took her Dean's advice to explore 'families and law beyond borders' (Boyd, 2019).

\footnotetext{
${ }^{1}$ As I have written in the acknowledgements section of the book, Professor David Nelken, the CUP Global Law series co-editor, was my guiding angel throughout the demanding process of turning the idea of legalised families in the era of bordered globalisation into a book.

${ }^{2}$ One stark example is the re-election of Viktor Orban as prime minister of Hungary, following a strikingly nationalist election campaign. See www.independent.co.uk/news/world/europe/hungary-general-election-viktor-orban-latest-christianity-nationalism-muslims-migrants-europe-racism-a8293836.html (accessed 6 March 2019). Shortly after his election, Orban acted to ban gender studies programmes. See www.independent.co.uk/news/world/europe/hungary-bans-gender-studies-programmes-viktor-orban-central-european-university-budapest-a8599796.html (accessed 6 March 2019).

${ }^{3}$ For example, on the Trump administration's recent separation of young children from their parents, see www.theguardian.com/us-news/2018/jul/26/trump-administration-family-separations-children-reunited (accessed 6 March 2019).

(C) Cambridge University Press 2019
} 
Israel is the only country in the world with a dual and hybrid family law system, which subjects its citizens to both civil and religious juristic elements. Among many other peculiarities of this abnormal situation, property division among divorcing Jewish couples can be decided by either the civil Family Court or the religious Rabbinical Court. ${ }^{4}$ However, even when the religious court rules on questions of property, it is allegedly governed by civil law and must not be influenced by religious norms on that matter (Dagan and Hacker, 2019). The case in question involved a couple who had been married for thirty-one years and who had lived for two decades in a house built on land that was inherited by the husband shortly before he married. According to the Israeli law governing matrimonial property, ${ }^{5}$ the latter does not include inherited property. Nevertheless, previous Supreme Court rulings allowed a divorcing spouse to claim shared ownership of inherited property under more general legal property or contractual doctrine, especially when the family residence is at stake. This ruling also binds the religious courts.

The case was first heard by the Regional Rabbinical Court, which implemented the civil law and ruled that, indeed, the woman was entitled to half the value of the house. ${ }^{6}$ The husband appealed to the Great Rabbinical Court, which reversed the ruling. Two of the three religious judges mentioned the fact that the woman had a new partner as proof that the husband never intended to share the ownership of the house with his wife. ${ }^{7}$ Indeed, a married woman's relationship with another man is among the most severe religious offences. The woman turned to the Supreme Court, arguing that the Great Rabbinical Court decision should be annulled, as it was based on religious norms of infidelity and hence breached the boundaries of its judicial authority.

The Supreme Court rejected the petition, with two judges against one (all male) arguing that the Great Rabbinical Court decision was within its judicial authority and should not be overruled. ${ }^{8}$ This decision was followed by a rare commotion within the legal community and the media. Some argued that it takes Israeli society and law back to the Dark Ages, ${ }^{9}$ while others focused on the issue of (so-called) infidelity, arguing either that it was not significant within the ruling or that it is indeed a relevant criterion within property division among divorcing spouses. ${ }^{10}$ Hence, as Lifshitz (2019) argues in his commentary,

'in certain countries, including Israel, where Hacker lives and works, the encounter between the liberal and the non-liberal groups becomes less and less a meeting between a liberal "landlord" that hosts the non-liberal minority group and is pondering the degree of tolerance towards the guests, and more like a meeting between two groups of equal standing that fight over the shaping of the public [and I would add, the private] sphere.' (p. $\mathrm{xx}-\mathrm{xx}$ )

While, as he details, in many Western countries, the law was changed at one time or another so as to detach divorce and its outcomes from 'fault', fault is part of Israeli family law and it also creeps into its civil aspects (see also Dagan and Hacker (2019)). Lifshitz highlights the potential of enriching the

\footnotetext{
${ }^{4}$ Each religious group is governed by its own religious courts, so there are also Sharia, Christian and Druze courts. As there is no civil marriage or divorce in Israel, only religious ones, these tribunals have sole jurisdiction also over secular citizens.

${ }^{5}$ Spouses Property Relations Act, 1973.

${ }^{6}$ Regional Rabbinical Court (Haifa) 927139/3 (unpublished, on file with author, 2 February 2016).

${ }^{7}$ Great Rabbinical Court 1073676/1 (Nevo, 27 July 2017).

${ }^{8}$ HCJ 4602/13 (Nevo, 11 November 2018). The decision has not yet been published in English. For more details in English, see www.haaretz.com/israel-news/.premium-high-court-denies-property-rights-to-adulterous-woman-1.6675240 (accessed 6 March 2019).

${ }^{9}$ For example, Ruth Halpern-Kaddari (20 November 2018), www.haaretz.co.il/opinions/.premium-1.6674274 (accessed 6 March 2019); Moshe Gorali (19 November 2018), www.calcalist.co.il/local/articles/0,7340,L-3750227,00.html (accessed 6 March 2019); Amy Bechor (26 November 2018), www.calcalist.co.il/local/articles/0,7340,L-3750685,00.html (all in Hebrew).

${ }^{10}$ For example, Yael Gil (21 November 2018), www.calcalist.co.il/local/articles/0,7340,L-3750367,00.html (accessed 6 March 2019); Arthur Shani (23 November 2018), www.calcalist.co.il/local/articles/0,7340,L-3750433,00.html (accessed 6 March 2019); Avivit Moskowitz (20 November 2018), www.ynet.co.il/articles/0,7340,L-5410169,00.html (accessed 6 March 2019) (all in Hebrew).
} 
dialogue between the 'camps', but I am concerned about old and new coalitions of male policy-makers sacrificing women's interests, be it due to pseudo-multiculturalism, judicial comity or the many faces of patriarchy.

But I wish to move away from the 'infidelity controversy' and to focus on one particular paragraph within the decision of one of the Supreme Court majority judges. Judge Alex Stein was recently 'imported' by the Minister of Justice to strengthen the anti-activist camp within the Supreme Court. After fourteen years spent teaching in American universities, he returned to Israel, to be nominated to the Supreme Court. ${ }^{11}$ This is an interesting manifestation of legal globorderisation that I did not discuss in the book: political cross-border importation of judges. The Minister of Justice 'shopped' abroad for what she perceived to be a conservative judge who suited her political agenda, which includes tightened borders between the government and the Supreme Court to prevent judges from overruling governmental decisions. The emigrant who left Israel is allowed back in, to be immediately nominated to the highest judicial position, as Israel does not annul its citizens' membership in the national collective, even if they leave the country to live abroad for many years.

The paragraph that I find most disturbing in Judge Stein's decision is this one:

'Spouses are allowed to live their lives as a couple in a religious, secular, patriarchal, feminist or other format that includes within it values and worldviews of diverse origin. Likewise, they are allowed to adopt for themselves a pattern of intimate living of their choosing, which may, or may not, include sexual freedom. All these matters are their private concern, and not our concern. The autonomy of the spousal system requires us to give neutral and equal treatment to all spousal life patterns and to all property arrangements, as long as they do not constitute abuse as prohibited by the law. ${ }^{, 12}$

As Suzanne Kim (2019) points out in her commentary, two of the aims of my book are to 'render visible the choices that drive so-called neutral legal principles and their application' ( $\mathrm{p}$. $\mathrm{xx}-\mathrm{xx})$ and to highlight the 'synthetic relationship between the public and private' ( $\mathrm{p} . \mathrm{xx}-\mathrm{xx}$ ). Indeed, while Judge Stein argues for 'neutrality', his stand erases decades of feminist struggles to lift the veil from the alleged neutrality of the law and the alleged separation between the public and the private spheres, and to reveal the harms it causes to women including within the family. The law cannot, and should not, be neutral. Judge Stein's apparent neutrality vis-à-vis whether the couple is 'patriarchal' or 'feminist' is not neutrality at all, but rather endorses the forsaking of women to the hands of the prevalent gendered power relations within marriage (Hacker, 2001). Indeed, these power relations - documented again and again in findings on the gendered labour division within families and within the labour force, and on the physical, emotional, sexual and economic violence inflicted by many husbands on their wives - directly affect what Judge Stein perceives as the 'spousal contract'. Like many transnational surrogacy contracts, discussed in the commentary of Ergas (2019), spousal contracts are, in many cases, not genuine contracts of mutual offer and acceptance, but rather the outcome of coerced practices shaped by patriarchal husbands, law and society. Judge Stein's use, in this short paragraph, of the words 'freedom', 'choosing', 'autonomy' and 'equal' is, in fact, a smokescreen that masks subordination, coercion, abuse and discrimination. In my opinion, this is but one example of the hijacking of the human rights discourse by political or economic right-wing forces that strive to weaken them (see also Dudai (2017)).

In the conclusion of the book - the only chapter not covered by this symposium - I sketch several basic normative principles that I suggest should guide legislators and judges who are dealing with families affected by bordered globalisation, if we aspire to create a humane and just society and world. Among these is the principle that legal phallocentrism should be acknowledged and corrected on the international, national and parochial levels. While I aim this moral message at legislators and

\footnotetext{
${ }^{11} \mathrm{See} \quad$ www.haaretz.com/israel-news/.premium-in-win-for-shaked-israel-appoints-u-s-prof-as-supreme-court-judge-1. 5845373 (accessed 6 March 2019).

${ }^{12} \mathrm{HCJ} 4602 / 13$, note 7 above, p. 31 . The translation to English is the author's.
} 
judges as a collective, I nevertheless also argue that the book demonstrates the power of individuals to challenge and shape families' laws (Hacker, 2017, p. 322): 'Each one of us - in our capacity as scholars, professionals, policymakers, and voters, and as family members, can make a difference. First, we have to shape an informed familial vision, and then we must act upon it.' The section of Judge Stein's decision on which I have focused here and the decision of the Israeli Supreme Court not to overrule the Great Rabbinical Court decision ${ }^{13}$ both exemplify the outcomes that are trickling down from the backlash on feminism and on human liberalism more generally, carried by the discourse of misogynist groups, religious fundamentalists, racist nationalists and extreme neoliberalists. I hope my book proves just how much we have to lose, at least on the familial front, if we do not fight back.

\section{References}

Boyd SB (2019) Familial citizenship and familial violence, in this volume.

Dagan H and Hacker D (2019) The specific shared ownership doctrine - towards the forth act in HCJ 4602/13. Law Studies forthcoming (in Hebrew).

Dudai R (2017) Entryism, mimicry and victimhood work: the adoption of human rights discourse by right-wing groups in Israel. The International Journal of Human Rights 21, 866-888.

Ergas Y (2019) Surrogacy: women's bodies between globalisation and national reform, in this volume.

Hacker D (2001) Single and married women in the law of Israel - a feminist perspective. Feminist Legal Studies 9, $29-56$.

Hacker D (2017) Legalized Families in the Era of Bordered Globalization. Cambridge: Cambridge University Press.

Hacker D (2019) Legalized families in the era of bordered globalization as a platform for future research: a heartfelt response to inspiring comments. Jerusalem Review of Legal Studies forthcoming.

Kim SA (2019) Intimacy in bordered globalisation: theory and method, in this volume.

Kohn NA (2019) Old age in an era of migrant elder care, in this volume.

Lifshitz S (2019) Co-ordinating family expectations, in this volume.

Renan Barzilay A (2019) Considering children's hunger in the era of bordered globalisation, in this volume.

\footnotetext{
${ }^{13} \mathrm{~A}$ petition to re-open this decision by a special procedure of 'further hearing' by a larger number of Supreme Court judges is currently pending.
}

Cite this article: Hacker D (2019). Facing the backlash: sketching the basic humane norms of families' laws. International Journal of Law in Context 15, 237-240. https://doi.org/10.1017/S174455231900020X 